\title{
SBDS wt Allele
}

National Cancer Institute

\section{Source}

National Cancer Institute. SBDS wt Allele. NCI Thesaurus. Code C97768.

Human SBDS wild-type allele is located in the vicinity of $7 q 11.21$ and is approximately $8 \mathrm{~kb}$ in length. This allele, which encodes ribosome maturation protein SBDS, is involved in the formation of the ribosome. Mutation of the gene is associated with Shwachman-BodianDiamond syndrome. 